\title{
НЕКОТОРЫЕ АСПЕКТЫ УЧАСТИЯ РОССОТРУДНИЧЕСТВА В ЭКСПОРТЕ РОССИЙСКОГО ОБРАЗОВАНИЯ "
}

\author{
(c) 2020 Забайкалов Андрей Павлович \\ кандидат юридических наук, доцент кафедры прикладного права \\ МИРЭА - Российский технологический университет, Россия, Москва \\ E-mail: zabaykalov@mail.ru
}

В статье рассмотрены отдельные аспекты участия Россотрудничества в процессе экспорта российского образования. В результате констатируется, что указанная деятельность осуществляется, прежде всего, в рамках национального проекта «Цифровая экономика Российской Федерации». Положения федерального проекта «Экспорт образования» играют менее значимую роль. Кроме того, отмечается утрата актуальности Концепции продвижения российского образования на базе представительств Россотрудничества за рубежом и формулируется предложение по выработке нового документы по данному вопросу. Результаты исследования могут быть использованы в практической деятельности по экспорту образования, а также для совершенствования нормативного и организационного обеспечения такой деятельности.

Ключевые слова: иностранный студент, образование, педагог, представительство, Россотрудничество, сайт, цифровая экономика, экспорт образования.

На современном этапе развития отечественного образования важность и необходимость осуществления активной деятельности по завоеванию и удержанию доли на мировом рынке образовательных услуг не вызывает сомнения. Вопросы экспорта высшего образования за рубеж являются актуальными и востребованными не только в Российской Федерации, но и во всех зарубежных странах [25, с.23]. Успех в данной сфере позволяет решить целый комплекс разнообразных задач, среди которых можно отметить следующие:

- развитие несырьевого сектора экономики;

- удовлетворение кадровых потребностей экономики;

- развитие науки;

- культурный обмен;

- смягчение демографических проблем;

- улучшение международного имиджа;

- расширение потенциала «мягкой силы» и т.д.

Ключевым программным инструментом, определяющим цели, задач и направления соответствующей государственной политики, выступает Федеральный проект «Экспорт образования» [17], входящий в национальный проект «Образование» [13]. При этом паспорт федерального проекта «Экспорт образования» подчерки- вает, что данный проект является продолжением приоритетного проекта «Развитие экспортного потенциала российской системы образования», утвержденного на период с 24 апреля 2017 г. по 15 ноября 2025 г. [14] Можно также отметить, что уже в 2002 году был утвержден План мероприятий по поддержке экспорта образовательных услуг образовательными учреждениями РФ [8]. То есть вопросы поддержки экспорта отечественного образования довольно давно находятся в центре внимания властей.

Среди прочего, федеральный проект «Экспорт образования» предусматривает создание ресурсных центров, которые предназначены для популяризации изучения в зарубежных странах на русском языке дисциплин, входящих в школьную программу. Число таких центров планируется последовательно увеличить с пяти в 2019 году до пятидесяти к 2024 году.

Для реализации данного мероприятия в 2019 году был сформирован консорциум из семи отечественных вузов [19]. Министерством науки и высшего образования Российской Федерации проведен конкурсный отбор для предоставления гранта в форме субсидий из федерального бюджет [10]. Подписаны соглашения с пятью школами, находящимися в таких странах как Республика Болгария, Киргизская Республика,

\footnotetext{
* Статья подготовлена в рамках гранта РФФИ 19-011-00959 «Моделирование экспорта высшего образования в рамках новых стратегий публичного управления в Российской Федерации» 2019-2021 г.г.
} 
Монголия, Республика Таджикистан и Турецкая Республика [19]. Таким образом, запланированные показатели на 2019 годы выполнены.

Интерес данные центры представляют, в том числе, в связи с тем, что они являются единственным примером, когда проект, заведомо рассчитанный на активность, направленную за пределы Российской Федерации, предполагает осуществление деятельности отечественных органов внешних сношений за границей. Указанные центры планируется создавать с использованием сети подведомственного Министерству иностранных дел Российской Федерации Россотрудничества (Федерального агентство по делам Содружества Независимых Государств, соотечественников, проживающих за рубежом, и по международному гуманитарному сотрудничеству) [18], а также российских центров науки и культуры, офисов транснациональных и российских компаний за рубежом.

Министерство иностранных дел Российской Федерации также указано как участник федерального проекта «Экспорт образования» в части разработки комплекса мер «по совершенствованию правил въезда в Российскую Федерацию и пребывания на ее территории иностранных граждан в целях обучения в российских образовательных организациях и трудоустройства в Российской Федерации». Однако данная деятельность все же ориентирована на территорию нашей страны.

В тоже время в рамках федерального проекта «Кадры для цифровой экономики» [15], входящего в национальный проект «Цифровая экономика» [12] установлено, что Россотрудничество выполнит целый ряд важных задач в сфере образования:

- организация повышения квалификации педагогов русских школ за рубежом по компетенциям, приоритетным для цифровой экономики;

- организация обучения учеников и работников русских школ за рубежом по программам тиражирования лучших практик в сфере развития цифровой грамотности;

- организация и проведение мероприятий просветительского и мотивационного характера, направленных на привлечение перспективных иностранных студентов для обучения в российских учреждениях высшего образования по IT-специальностям, а также специальностям, которые востребованы цифровой экономикой.
Фактически всего за 2019 год было проведено 158 очных и 115 заочных мероприятия в 93 странах [6]. Данные за 2020 год пока не обобщены.

Значительная часть данной работы выполнена посредством грантовой поддержки проектов на конкурсной основе. Всего было поддержано 27 грантополучателей по шести направлениям:

- международные конкурсы и олимпиады по цифровой экономике;

- цифровые технологии в образовательном процессе;

- онлайн-кружки по IT;

- взаимодействие российских и зарубежных образовательных организаций;

- цифровые образовательные ресурсы;

- сетевые образовательные курсы для учителей русских школ за рубежом [2].

Из данного перечня следует, что, как справедливо отметил глава Россотрудничества Е.А.Примаков, «вопрос заключается не столько в увеличении квот для поступления на территории РФ, а в создании, расширении площадок для получения российского образования за рубежом» [7].

Необходимо отметить, что в настоящее время на официальной странице Россотрудничества [11] в рамках описания такого вида деятельности как «Образование и наука» представлен раздел «Экспорт российского образования». Однако он наполнен практически только общими тезисами о продвижении российского образования за рубежом и новостями о проведенных мероприятиях. Также представлены сведения об отдельных проектах, в реализации которых принимает участие Россотрудничество: «Кадры для цифровой экономики»; «Профессии будущего»; «Знания дома» и т.д.

Отдельно на сайте имеется раздел «Отбор иностранных граждан на обучение в России в пределах квоты ...». В нем размещены сведения о размере квот, порядке отбора иностранцев для обучения в пределах квот, а также контактная информация. Здесь же имеется прямая ссылка на специальный сайт (систему) для сбора заявок на обучение в России (future-in-russia.com) [26], оператором которого выступает также Россотрудничество. Данный ресурс предлагает выбор примерно из 14000 образовательных программ, реализуемых в более чем 500 отечественных вузах (включая филиалы).

Также одним из проектов Россотрудничества является образовательный проект (сервис) 
«Учись в России!» (rs.physicon.ru) [23], который предполагает создание системы онлайн-курсов, контент которых соответствует российским стандартам и позволяет в достаточной мере освоить материал для поступления в образовательные учреждения Российской Федерации. Причем многие рутинные операции происходят автоматизировано, что позволяет преподавателю-куратору работать более эффективно и индивидуально. В настоящее время его планируется протестировать в ряде стран ближнего зарубежья [1].

Указанные сайты и, прежде всего, систему сбора заявок на обучение в России (futurein-russia.com), не следует путать с официальным сайтом о высшем образовании в России для иностранных студентов (studyinrussia.ru) [11], поддерживаемым Федеральным государственным автономным научным учреждением «Социоцентр» по государственному заданию Министерства науки и высшего образования Российской Федерации. Последний имеет более широкое информационное наполнение, что связано с иными целями его создания.

Кроме того, сайт «Образование в России для иностранных граждан» (russia-edu.ru) [9], при помощи которого можно подобрать образовательное учреждение и образовательную программу для бесплатного обучения в пределах квоты, установленной Правительством, а также отслеживать статус заявления на обучение, поддерживается также Министерством науки и высшего образования Российской Федерации.

Таким образом, у иностранных граждан, проявляющих интерес к российскому образованию, в настоящее время имеются информационные и образовательные ресурсы. Однако наполнение каждого из них отдельно не позволяет удовлетворять все потребности.

В связи с этим в рамках задачи «Внедрение цифровых технологий и платформенных решений в сферах государственного управления и оказания государственных услуг, в том числе в интересах населения и субъектов малого и среднего предпринимательства, включая индивидуальных предпринимателей» Федерального проекта «Цифровое государственное управление» [16], входящего в национальный проект «Цифровая экономика», предусмотрено создание и обеспечение функционирования цифровой платформы «Образование в РФ для иностранцев». Ответственным за достижение указанного результата также является Россотрудничество.

В начале 2020 года Россотрудничество заключило контракт на создание первой очереди государственной информационной системы «Образование в Российской Федерации для иностранцев», ее опытную эксплуатацию и техническую поддержку до конца 2021 года на общую сумму 229000000 рублей [4]. Предполагается создание виртуального мультиязычного «единого окна», объединяющего информационный портал об образовании в России для иностранных граждан, сервис поиска мест учебы, практик, стажировок и иных образовательных услуг, а также сервиса по подаче документов, в том числе, миграционных [20]. В ноябре 2020 уже началось онлайн-обучение работе с данной системой [22]. Внедрить же ее собираются в 2021 году после окончания пандемии новой коронавирусной инфекции [21].

При этом еще в 2014 году была подписана Концепция продвижения российского образования на базе представительств Россотрудничества за рубежом [5]. Данный документ не имеет нормативной силы, однако отражает:

- видение современного (на момент подписания) состояния «трансграничного» образования в России и роли Россотрудничества в экспорте российского образования за рубеж;

- цели, на которые направлено продвижение отечественного образования с применением представительств Россотрудничества за рубежом;

- механизмы, посредством которых предполагается продвижение отечественного образования с использованием возможностей представительств Россотрудничества за рубежом;

- порядок реализации самой концепции;

- вопросы организации учета и оценки эффективности работы по продвижению отечественного образования с применением представительств Россотрудничества за рубежом;

- признание значимости информационного сопровождения.

В целом можно отметить актуальность многих положений указанной Концепции, которые воплощаются в деятельности Россотрудничества:

- о необходимости содействию продвижения отечественных образовательных программ и проектов, в том числе с использованием «дистанционных коммуникативных технологий»;

- о важности развития партнерских связей 
между отечественными и иностранными образовательными организациями;

- о презентационной работе в сфере экспорта образования (организации соответствующих мероприятий и привлечении отечественных образовательных учреждений к участию в мероприятиях, организованных иными лицами).

Однако в других аспектах Концепция продвижения российского образования на базе представительств Россотрудничества за рубежом явно утратила актуальность. Она не только опирается на нормативные и иные акты, утратившие силу (в частности, Концепцию внешней политики Российской Федерации 2013 г. и Государственную программу Российской Федерации «Развитие образования» на 2013-2020 годы), но и не соответствует современным тенденциям публичного управления. В связи с этим можно предложить разработать новую концепцию участия Россотрудничества в экспорте российского образования, учитывающую:

1. современные мировые и российские реалии;

2. новые задачи, которые поставлены данному органу власти, как в рамках национального проекта «Цифровая экономика Российской Федерации», так и в рамках федерального проекта «Экспорт образования»;

3. традиции и наработки, связанные со спецификой деятельности Россотрудничества.

Это предложение тем более актуально, что глава Россотрудничества заявил: «Россотрудничество ждут большие перемены. Не будет костров инквизиции ... Но поменяется очень многое» [3].

\section{Библиографический список}

1. В России появился сервис подготовки иностранцев к поступлению в вузы РФ. - URL: https://rg.ru/2020/10/28/ v-rossii-poiavilsia-servis-podgotovki-inostrancev-k-postupleniiu-v-vuzy-rf.html (дата обращения: 01.12.2020).

2. Всё, что нужно знать о грантах Россотрудничества. - URL: https://rusdigitalcoop.com/grants/ (дата обращения: 01.12.2020).

3. Глава Россотрудничества рассказал, каким видит будущее агентства. - URL: https://tass.ru/politika/8816649 (дата обращения: 01.12.2020).

4. Контракт № 1770470675820000019._ URL: https://zakupki.gov.ru/epz/contract/contractCard/common-info.ht ml?reestrNumber=1770470675820000019 (дата обращения: 01.12.2020).

5. Концепция продвижения российского образования на базе представительств Россотрудничества за рубежом: утв. МИД России 27 марта 2014 г._- URL: https://base.garant.ru/70892382/ (дата обращения: 01.12.2020).

6. Мероприятия Россотрудничества в рамках нацпроекта «Цифровая экономика России». Результаты 2019 года. - URL: http://rdcu.ru/results2019 (дата обращения: 01.12.2020).

7. Немченко Ю. Евгений Примаков: Россотрудничество заговорит на понятном для зарубежной аудитории языке. - URL: https://tass.ru/interviews/8925417 (дата обращения: 01.12.2020).

8. Об утверждении плана мероприятий по поддержке экспорта образовательных услуг образовательными учреждениями РФ: распоряжение Правительства РФ от 1 ноября 2002 г. № 1536-р // Собрание законодательства Российской Федерации. 2002. № 45. Ст. 4525.

9. Образование в России для иностранных граждан.- URL: https://www.russia-edu.ru/(дата обращения: 01.12.2020).

10. Объявление о проведении в 2019 году отбора и документация о конкурсном отборе на предоставление грантов в форме субсидий из федерального бюджета ... в 2019 году (шифр конкурсного отбора 2019-25613-ЭО-7).- URL: https://minobrnauki.gov.ru/documents/? ELEMENT_ID=18690\&sphrase_id=27363 (дата обращения: 01.12.2020).

11. Официальный сайт о высшем образовании в России для иностранных студентов. - URL: https://studyinrussia. $\mathrm{ru}$ / (дата обращения: 01.12.2020).

12. Паспорт национального проекта «Национальная программа «Цифровая экономика Российской Федерации»: утв. Президиумом Совета при Президенте РФ по стратегическому развитию и национальным проектам (протокол от 4 июня 2019 г. № 7). - URL: https://digital.gov.ru/ru/activity/directions/858/\#section-events (дата обращения: 01.12.2020).

13. Паспорт национального проекта «Образование»: утв. президиумом Совета при Президенте РФ по стратегическому развитию и национальным проектам (протокол от 24 декабря 2018 г. № 16). - URL: http:// government.ru/info/35566/ (дата обращения: 01.12.2020). 
14. Паспорт приоритетного проекта «Развитие экспортного потенциала российской системы образования»: утв. Президиумом Совета при Президенте РФ по стратегическому развитию и приоритетным проектам (протокол от 30 мая 2017 г. № 6)._- URL: http://www.consultant.ru/document/cons_doc_LAW_217871/ (дата обращения: 01.12.2020).

15. Паспорт федерального проекта «Кадры для цифровой экономики»: приложение № 4 к протоколу президиума Правительственной комиссии по цифровому развитию, использованию информационных технологий для улучшения качества жизни и условий ведения предпринимательской деятельности от 28 мая 2019 г. № 9.- URL: https://digital.gov.ru/ru/activity/directions/858/\#section-events (дата обращения: 01.12.2020).

16. Паспорт федерального проекта «Цифровое государственное управление»: приложение № 7 к протоколу президиума Правительственной комиссии по цифровому развитию, использованию информационных технологий для улучшения качества жизни и условий ведения предпринимательской деятельности от 28 мая 2019 г. № 9.- URL: https://digital.gov.ru/ru/activity/directions/858/\#section-events (дата обращения: 01.12.2020).

17. Паспорт федерального проекта «Экспорт образования»: приложение к протоколу заседания проектного комитета по национальному проекту «Образование» от 07 декабря 2018 г. № 3.- URL: https://futurerussia. gov.ru/eksport-obrazovania (дата обращения: 01.12.2020).

18. Положение о Федеральном агентстве по делам Содружества Независимых Государств, соотечественников, проживающих за рубежом, и по международному гуманитарному сотрудничеству: утв. Указом Президента РФ от 6 сентября 2008 г. № 1315 // Собрание законодательства Российской Федерации. 2008. № 37. Ст. 4181.

19. Ресурсные центры российского образования - новый формат довузовской подготовки абитуриентов за рубежом._-URL: https://minobrnauki.gov.ru/press-center/news/? ELEMENT_ID=22815\&sphrase_id=27363 (дата обращения: 01.12.2020).

20. Россотрудничество доделывает окно для иностранных студентов.- URL: https:/www.vedomosti.ru/society/ articles/2020/11/30/848898-rossotrudnichestvo-dodelivaet (дата обращения: 01.12.2020).

21. Россотрудничество создаст сервис «единого окна» для иностранных студентов.- URL: https://www.pnp.ru/ politics/rossotrudnichestvo-sozdast-servis-edinogo-okna-dlya-inostrannykh-studentov.html (дата обращения: 01.12.2020).

22. Россотрудничество. Обучение по работе с ГИС «Образование в Российской Федерации для иностранцев».URL: https://arm.rs.gov.ru/ru/news/79576 (дата обращения: 01.12.2020).

23. Учись в России! - URL: https://rs.physicon.ru (дата обращения: 01.12.2020).

24. Федеральное агентство по делам Содружества Независимых Государств, соотечественников, проживающих за рубежом, и по международному гуманитарному сотрудничеству: официальный сайт. - URL: https:// rs.gov.ru/ru (дата обращения: 01.12.2020).

25. Щукина Т.В. Экспорт российского высшего образования за рубеж: нормативно-правовое регулирование и стратегические цели развития // Вопросы экономики и права. 2019. № 136.- С. 23-26.

26. The system for collecting applications for study in Russian Federation. - URL: https://future-in-russia.com/ (дата обращения: 01.12.2020). 